Section Editor

Mitchell S.V. Elkind,

MD, MS

Floris H.B.M. Schreuder, MD

Rinske M.P.T. Hamers, MD

Peter H.M.F. van

Domburg, MD, PhD

Address correspondence and reprint requests to Dr. Floris H.B.M. Schreuder, Department of Neurology, Maastricht University Medical Centre, Postbox 5800, 6202 AZ Maastricht, the Netherlands f.schreuder@mumc.nl

\title{
Teaching NeuroImages: Holmes tremor after midbrain stroke
}

宫

\section{Figure $1 \quad$ T2-weighted image showing circumscribed ischemia of the left ventromedial midbrain}

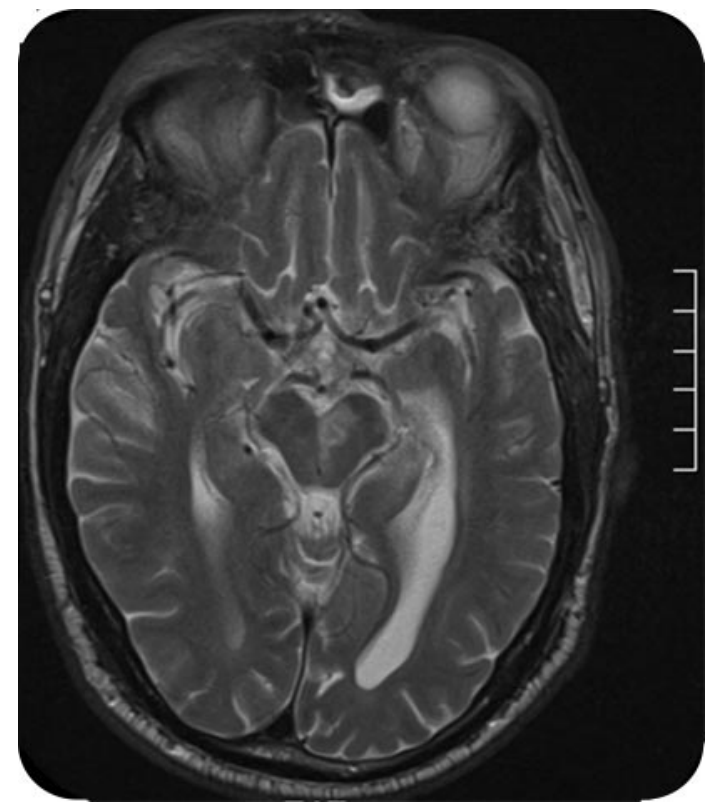

A 69-year-old man presented with a continuous right upper extremity resting tremor with a $3-\mathrm{Hz}$ frequency (video on the Neurology ${ }^{\circledR}$ Web site at www. neurology.org). The tremor developed gradually, 4 months after a left midbrain stroke. MRI showed an infarct in the left medioventral midbrain (figure 1). $\left[{ }^{123} \mathrm{I}\right]-2 \beta$-carbomethoxy-3 $\beta$-(4-iodophenyl)- $N$-(3fluoropropyl)-nortropane ([ $\left.\left.{ }^{123} \mathrm{I}\right] \mathrm{FP}-\mathrm{CIT}\right)$ SPECT revealed marked left dopaminergic denervation (figure 2). At follow-up, the drug-resistant tremor had progressed to a predominantly postural and kinetic tremor.

Holmes tremor is an irregular rest, kinetic, or postural tremor with a frequency below $4.5 \mathrm{~Hz}$. It is

\section{Figure 2 [ $\left.{ }^{123}\right]$ FP-CIT SPECT showing reduced uptake within the left putamen and caudate}

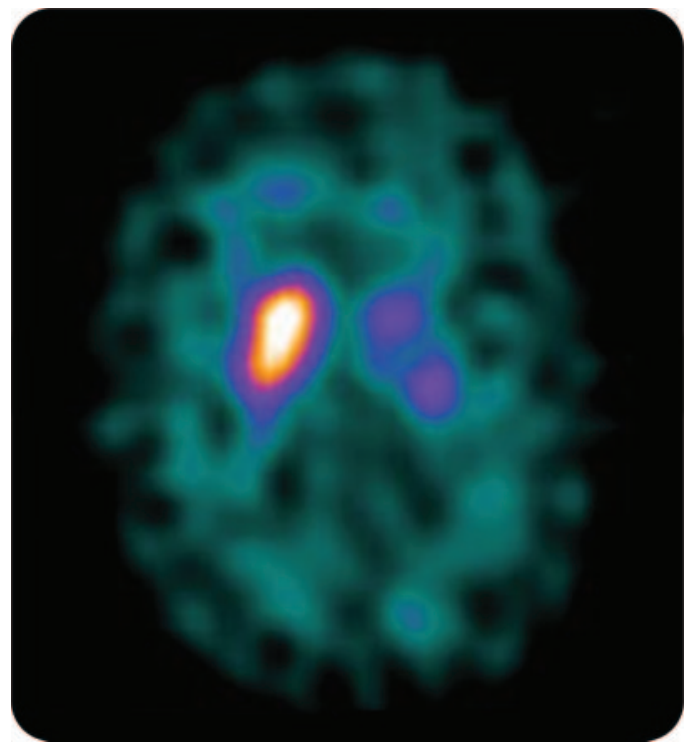

$\left[{ }^{123} \mid\right] \mathrm{FP}-\mathrm{CIT}=\left[{ }^{123} \mid\right]-2 \beta$-carbomethoxy-3 $\beta$-(4-iodophenyl)$\mathrm{N}$-(3-fluoropropyl)-nortropane.

caused by a combined disruption of dopaminergic nigrostriatal, and cerebellorubrothalamic tracts. ${ }^{1} \mathrm{~A}$ delay of up to 2 years between the lesion and tremor onset is typical. Case reports suggest that pharmacologic or neurosurgical intervention may help. ${ }^{1,2}$

Received September 20, 2009. Accepted in final form March 31, 2010.

\section{REFERENCES}

1. Seidel S, Kasprian G, Leutmezer F, Prayer D, Auff E. Disruption of nigrostriatal and cerebellothalamic pathways in dopamine responsive Holmes' tremor. J Neurol Neurosurg Psychiatry 2009;80:921-923.

2. Diederich NJ, Verhagen Metman L, Bakay RA, Alesch F. Ventral intermediate thalamic stimulation in complex tremor syndromes. Stereotact Funct Neurosurg 2008;86: 167-172.
Supplemental data at www.neurology.org

From the Department of Neurology (F.H.B.M.S.), Maastricht University Medical Centre; and Department of Neurology (F.H.B.M.S., R.M.P.T.H., P.H.M.F.v.D.), Orbis Medical Centre, Sittard, the Netherlands.

Disclosure: Dr. Schreuder and Dr. Hamers report no disclosures. Dr. van Domburg has served on scientific advisory boards for Novartis and Lundbeck Inc. 


\section{Neurology}

Teaching NeuroImages: Holmes tremor after midbrain stroke

Floris H.B.M. Schreuder, Rinske M.P.T. Hamers and Peter H.M.F. van Domburg

Neurology 2010;75; 10

DOI 10.1212/WNL.0b013e3181ea1545

This information is current as of July 26, 2010

Updated Information \&

Services

Supplementary Material

References

Subspecialty Collections

Permissions \& Licensing

Reprints including high resolution figures, can be found at:

http://n.neurology.org/content/75/4/e10.full

Supplementary material can be found at:

http://n.neurology.org/content/suppl/2010/07/24/75.4.e10.DC1

This article cites 2 articles, 1 of which you can access for free at: http://n.neurology.org/content/75/4/e10.full\#ref-list-1

This article, along with others on similar topics, appears in the following collection(s):

All Cerebrovascular disease/Stroke

http://n.neurology.org/cgi/collection/all_cerebrovascular_disease_strok e

MRI

http://n.neurology.org/cgi/collection/mri

Tremor

http://n.neurology.org/cgi/collection/tremor

Information about reproducing this article in parts (figures,tables) or in its entirety can be found online at:

http://www.neurology.org/about/about_the_journal\#permissions

Information about ordering reprints can be found online:

http://n.neurology.org/subscribers/advertise

Neurology ${ }^{\circledR}$ is the official journal of the American Academy of Neurology. Published continuously since 1951, it is now a weekly with 48 issues per year. Copyright . All rights reserved. Print ISSN: 0028-3878. Online ISSN: 1526-632X.

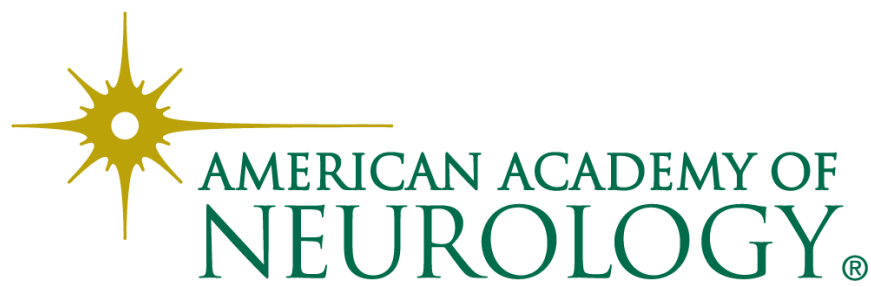

